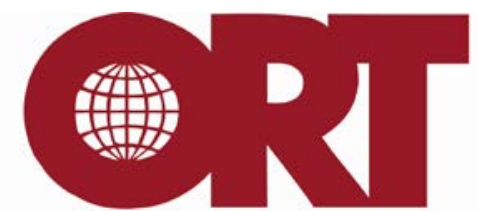

UNIVERSIDAD ORT

Uruguay

\title{
The impact of bank credit on employment formality in Uruguay
}

\author{
Gandelman, Néstor \\ Universidad ORT Uruguay \\ Rasteletti, Alejandro \\ Inter American Development Bank \\ $*$
}

Mayo de 2012

\begin{abstract}
This paper examines the effect of bank credit on employment formalization in Uruguay. Using a differencein-differences methodology proposed by Catão, Pagés and Rosales (2011), the paper finds that financial deepening decreases informality, especially in more financially dependent sectors. The effect is additionally found to be larger for women and younger workers. Despite the severe economic crisis and a sharp contraction of bank credit experienced by the economy in the period of analysis, no evidence is found that the effect of bank credit on employment formality has changed over time.
\end{abstract}

JEL classifications: E26, G21, O4, O16

Keywords: Credit market, Informality, Uruguay

Documento de Investigación, Nro. 75, mayo 2012. Universidad ORT Uruguay.

Facultad de Administración y Ciencias Sociales. ISSN 1688-6275

\footnotetext{
* The authors thank Luis Catão and Paulo Bastos for helpful comments and suggestions and Juan Alberti and Diego Lamé for their research assistance. All errors and omissions are the authors' sole responsibility. The opinions expressed in this paper are those of the authors and do not necessarily reflect the views of the Inter-American Development Bank or its Board of Directors, or the countries they represent.
} 


\section{Introduction}

There is a large academic literature studying the effects of financial development on economic growth. ${ }^{1}$ The main reason why economists think financial development should foster growth is that the more developed financial markets are, the fewer firms will be financially constrained and the larger the number of investment projects will be undertaken. This in turn should foster economic growth. A similar line of reasoning is used to explain why informality hurts growth. ${ }^{2}$ In order to avoid regulations while informal, firms decide not to undertake investment projects in order to remain small and undetected by government regulation. This leads to inefficient production scales and hurts economy growth.

Despite the similarities in arguments used, not many studies have looked at the interrelations between financial development and informality, and how these affect growth. Financial development might reduce informality by increasing the opportunity cost of being informal. To have access to credit from banks and other regulated agencies, firms typically have to be registered and disclose information. While deciding on whether to be formal, firm managers should take into account that informality limits access to finance. In less developed financial markets, the cost of being an informal firm should be lower, given that access to finance is limited and the cost of borrowing high. In more developed financial markets, access to finance tends to be relatively easier and the cost of borrowing lower. This should then increase the opportunity cost of being informal.

It is also possible that the extent of informality among firms affects financial market development. In economies with high levels of informality the cost of lending to an average firm tends to be higher, given the higher cost of monitoring informal firms. Due to the higher cost of providing financing, firms might decide not to participate in financial markets, which can be detrimental to the process of financial development.

This paper contributes to the literature on financial development, informality and economic growth by studying the effect of bank credit on informality in a developing country. To our knowledge, only the work of Catão, Pagés and Rosales (2011) has studied the relation between access to credit and informality. Their work uses sectoral differences in financial needs

${ }^{1}$ Levine (1997); Beck, Levine, and Loayza (2000).

2 Farrell (2006); Perry et al. (2008); Levy (2008); La Porta and Shleifer (2008); D’Erasmo and Moscoso Boedo (2009); Hsieh and Klenow (2009). 
to identify this relation. More specifically, if financial deepening affects formalization, easier access to credit should affect formalization relatively more in sectors that have a higher dependence on financing. Using Brazilian data from 2002 to 2007, they find that financial deepening led to higher employment formalization rates in sectors where firms are typically more dependent on external finance. We apply their methodology to study whether changes in financial deepening had an effect on formality in Uruguay in the years 2000 to 2010.

Uruguay is an interesting case study of the link between informality and credit access for two reasons. First, when compared to other Latin American countries, Uruguay stands out due to its low ratio of credit to GDP as well as for its low level of employment informality. In 2010, domestic credit provided by the banking sector in Uruguay reached only reached an equivalent of 30 percent of GDP, while the average for Latin American countries was 15 percentage points higher. In regard to employment informality, according to ILO Statistics (2011), 39.8 percent of employees in Uruguay are informal. This number is significantly lower than the average of 58.7 percent for the other 15 Latin American countries reported. Second, Uruguay is an interesting case study because in 2002 it experienced a deep economic and financial crisis, followed by a period of rapid economic growth. This allows the study of the effect of credit on informality in different phases of the business cycle.

Our results suggest that bank credit growth fostered formalization in Uruguay, especially in sectors that are more financially dependent. The positive effect found is consistent with that in Catão, Pagés and Rosales (2011), who use Brazilian data that only cover a period of economic expansion. We also find that for some groups of workers the effect of bank credit on informality is stronger. These groups include young workers and female workers. No evidence is found that the effect of bank credit on formality changed in the different phases of the business cycle.

The rest of this paper is organized as follows. In Section 2 we present the definitions of the main variables used in the analysis as well as the data sources. Section 3 discusses recent developments in the Uruguayan economy regarding the variables of interest. Section 4 presents the methodology used and discusses results, and Section 5 concludes.

\section{Variable Definitions and Data Sources}


To study the effect of bank credit on informality in Uruguay we construct a pseudo-panel dataset, $^{3}$ given the lack of a dataset with information on informality or credit at the firm level. The pseudo-panel dataset consists of synthetic observations obtained from averaging observations for different groups with similar time-invariant characteristics, in a sequence of repeated cross-sectional datasets. In this paper we use repeated cross-sectional household surveys, which cover the years 2000 to 2010. To construct the dataset, observations from the household surveys are averaged across the economic sector and calendar year dimensions. We use the 2-digit ISIC Revision 3 for sector aggregation. The dataset created contains information on informality, credit and financial dependence. Definitions and data sources for each of these variables are indicated below.

\subsection{Informality}

Although related, employment informality and firm informality are not equivalent. Many established firms pay their workers below national minimum wages, leave their workers without social protection programs or simply do not declare them to the relevant public institutions. On the other hand, some formal employees may work in firms that are simply covering illegal or partially illegal activities (e.g., some importers may smuggle or not pay the required tariffs for all their imports). Given the lack of data on firm formality, the literature on informality in Uruguay has focused on employment informality as measured by household surveys. ${ }^{4}$

Researchers have tended to use three different approaches for measuring employment informality. Following International Labour Organization suggestions, informality can de defined according to sector, type of jobs and size of establishment. ${ }^{5}$ This methodology is easy to

\footnotetext{
${ }^{3}$ There is vast literature regarding under which conditions parameters can be consistently estimated given the limitations that arise when working with pseudo-panel instead of real panel data. Part of that literature can be found in Deaton (1985), Moffitt (1993), Verbeek and Vella (2002) and Antman and McKenzie (2005), among others.

${ }^{4}$ Assuming that informal activities have to be carried out in cash, some authors have measured the size of the informal sector from money demand in "excess" of fundamentals (see Graziani, 1988; and Brasca et al., 2009). These measures are controversial because of estimation issues, simplifying assumptions and some contradictions with other sources of information. Moreover, this is not an appropriate method for this project since it does not allow constructing sector-based measures of informality.

${ }^{5}$ Diez de Medina and Gerstenfeld (1986) define informal employment as self-employed workers (excluding professionals), non-salary family workers and workers in establishments of four or less employees. Other authors make variations over this definition including for instance the domestic service and establishments of five or less employees. See Longhi (1999), Instituto Cuesta Duarte (2002), Filgueira and Gelber (2003) and Amarante and Arim (2005).
} 
implement and to follow over time. A drawback of this approach, however, is that it does not truly capture informality but merely assumes that certain tasks and certain small firms are probably informal.

A second approach, following the work of Cassoni (2000), uses data from health coverage to build a measure of employment informality. As every formal worker in Uruguay has rights to health coverage at a private health maintenance organization (HMO), Cassoni measures employment informality as the percentage of active workers who do not have rights in any HMO. The strength of this approach is that workers are not likely to lie about their health coverage, which is in a separate section not related to the income or work sections of the questionnaire. On the other hand, this measure fails to capture workers at firms that for tax and social security reasons declare only a proportion of their current wage and informal workers who pay an HMO out-of-pocket.

The final approach to measuring employment informality looks at whether the worker has right to an "aguinaldo" or if the worker (or his employers) make in full the required payments to social security that would grant him rights to a pension in the future. ${ }^{6}$ These questions, which were incorporated into the household survey in 2001, capture the essence of employment informality. The main problem with them, though, is that they may suffer from significant misreporting.

Using data from Household Surveys (ECH) ${ }^{7}$ produced by Uruguay’s National Institute of Statistics (INE), we create three alternative measures of informality, based on the second and third approaches mentioned above. The first measure, which we call "health rights," defines a worker as informal if he or she does not have an HMO, despite being employed. According to our second measure, a worker is considered informal if he or she does not receive a thirteenth salary. We call this measure "Aguinaldo." The third and last measure classifies a worker as informal if he or she does not pay social security taxes. We call this measure "social security." The health right measure is available for the years 2000 through 2010, while the other two measures are available starting in 2001. Once workers are classified as formal or informal

\footnotetext{
${ }^{6}$ The aguinaldo is a thirteenth monthly bonus salary that Uruguayan workers receive by law, half of it in June and half of it in December.

${ }^{7}$ The surveys cover every urban area (cities and towns) with more than 5,000 inhabitants. For each private household in the survey, the dataset has information on all people habitually living there.
} 
according to the different measures, we construct the sector-level measure of informality by calculating the proportion of workers in a given sector and year who are informal. These proportions are calculated only for workers 14 years of age or older. Sectors with fewer than 50 observations in the household survey in a given year are dropped due to measurement error concerns.

Naturally, there are differences in the levels of informality reported in the three measures (see Figure 4 and Table A1 in the Appendix). For the last year in our sample, informality reached 35 percent according to the social security measure and about 41 percent according to the aguinaldo and health rights measures. For all years in the sample, the social security measure of informality was lower than the other two measures, which can be expected given the natural reporting bias. Despite the differences, all three measures of informality are highly correlated. Table 1 shows the correlations for the sector aggregates for the 40 sectors studied.

Table 1. Correlation between Alternative Measures of Informality

\begin{tabular}{|c|c|c|c|}
\hline & Social Security & Aguinaldo & Health Rights \\
\hline $\begin{array}{c}\text { Social Security } \\
\text { Tax }\end{array}$ & $1.00^{* * *}$ & - & - \\
\hline Aguinaldo & $0.93^{* * *}$ & $1.00^{* * *}$ & - \\
\hline Health Rights & $0.97^{* * *}$ & $0.93^{* * *}$ & $1.00^{* * *}$ \\
\hline
\end{tabular}

* Significant at $10 \%$; ** significant at $5 \%$; *** significant at $1 \%$. Correlations are defined at the sector level and are estimated for the years 2001 to 2010.

Finally, it is should be noted that informality in Uruguay differs greatly across sectors; Table A1 reports sector-level informality in three different years. Some sectors, such as manufacturing of furniture (ISIC sector 36) and construction (ISIC sector 45), display high levels of informality, exceeding 50 percent. On the other hand, sectors such as manufacturing of rubber and plastic products (ISIC sector 25) and manufacturing of chemicals and chemical products (ISIC sector 24) display informal employment of less than 15 percent. Dispersion is also observed along other breaks in the data. Table A2 reports informality measures according to various breaks that are considered in Section 4 below. Informality is larger among workers employed by smaller firms. Informality also seems to be higher for younger workers, although 
this is not true when the aguinaldo definition of informality is used. Finally, in our sample, informality is greater among male workers than female workers.

\subsection{Credit}

In this paper we are interested in studying how bank credit affects informality levels. Measuring credit availability is difficult, however, since there are no data on firm-level credit access. Moreover, if this data were available, their utility for this study would be limited by their endogeneity. Given this problem, we follow Catão, Pagés and Rosales (2011) and use the ratio of credit to the private sector to GDP, measured at the country-year level, as a proxy for credit availability.

We focus on banking credit because it is the most important source of external funding for firms in Uruguay, as reported by various authors (e.g., Munyo 2005, de Brun et al 2003). ${ }^{8}$ To construct the credit measures, we use data from different sources. The data on credit to private sector, produced by the Superintendency of Financial Services of the Central Bank of Uruguay (BCU), include the lending of both private and public banks; these data are a time series with monthly observations. Given that we construct interannual informality results from the household surveys, we decided to construct our measure of credit in a given year as the annual average of the monthly stocks. The GDP measure also comes from the BCU.

\subsection{External Financing Dependence}

Some authors believe that technological factors make some industries more dependent than others on external finance. According to Rajan and Zingales (1998), such factors may include differences between industries in initial project scales, gestation and cash harvest periods and the requirement for continuing investment. Furthermore, they argue that these technological differences are likely to persist across countries, so an industry's dependence on external financing as identified in a given country could be used as a measure of its dependence in other countries. Following Rajan and Zingales (1998), Catão, Pagés and Rosales (2011) construct an

\footnotetext{
${ }^{8}$ Munyo (2005) found that $60 \%$ of corporate financing needs were met through borrowing and $40 \%$ from retained earnings. Reliance on bank credit was on average as great as on trade credit, though larger companies with greater tangible assets tended to rely proportionally more on bank rather than trade financing, and had greater access to longterm financing.
} 
external financing dependence index, using information from the sample of U.S. firms in the S\&P 1500 index for the years 2000-2010. We use their measure in this paper.

The Catão, Pagés and Rosales (2011) external financing dependence index ${ }^{9}$ is defined as the ratio between capital expenditures minus cash from operations (use of external finance) and capital expenditures. For each firm the ratio is calculated as the sum of external financial use for the 2000-2010 period and the sum of capital expenditures for the same period. A sector's financial dependence is calculated as the median index for the firms in that sector. Using the index forces us to drop 10 sectors that have informality data but are not covered in the external financing dependence measure. Two of these sectors are important in terms of employment, each accounting for more than 10 percent of working adults: agriculture and domestic workers. Forestry and financial intermediation were also dropped, with each employing only 1 percent of the working population. ${ }^{10}$ Overall, our data cover the vast majority of workers. In 2010, the data covered 75 percent of all workers.

\section{The Evolution of Credit and Informality in Uruguay during the Economic Crisis and Recovery}

After growing by 3.9 percent a year on average between 1990 and 1998, in 1999 Uruguay entered a recession period that ended in a profound financial and economic crisis in the second quarter of 2002, a year in which GDP contracted by 7.7 percent. After the crisis, the Uruguayan economy entered a strong recovery period (see Figure 1), with an average growth rate of 6.2 percent between 2004 and 2010.

\footnotetext{
${ }^{9}$ We thank Luis Catão for providing these data.

${ }^{10}$ The other sectors are the following: fishing, operation of fish hatcheries and fish farms; insurance and pension funding; activities auxiliary to financial intermediation; research and development; compulsory social security and activities of membership organizations n.e.c.
} 


\section{Figure 1. Evolution of GDP (in million U\$S)}

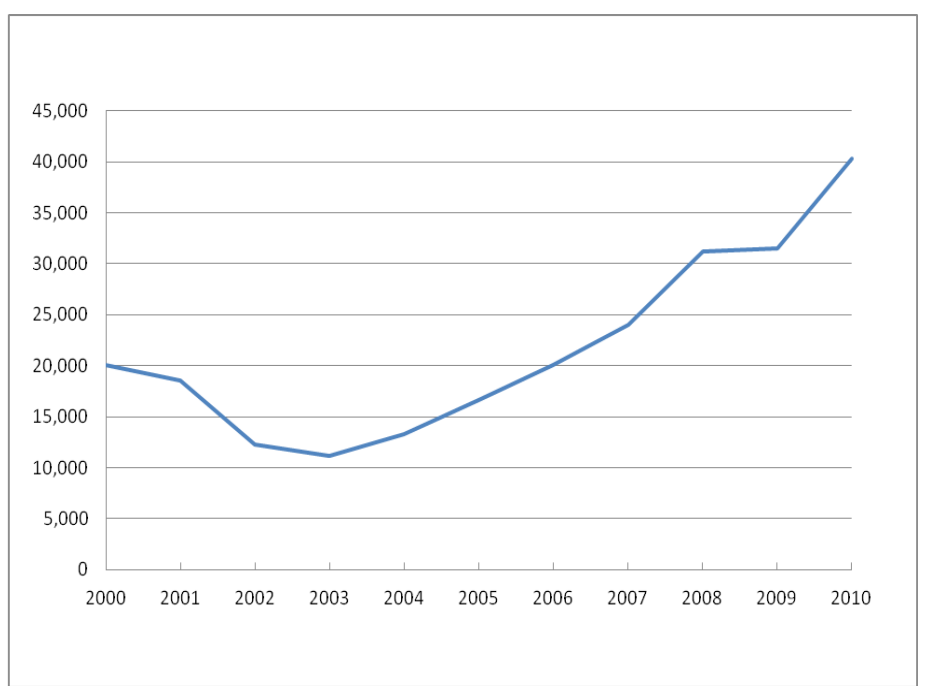

The 2002 financial crisis was triggered by a run on banks, a large currency devaluation and a default on sovereign debt in neighboring Argentina. Fear soon spread to the financial system in Uruguay, which had large deposits from Argentine citizens. In the first nine months of 2002, peso-denominated deposit in Uruguayan banks fell by 15.6 percent and dollar-denominated deposits by 56.5 percent. The Uruguayan government was forced to let the currency depreciate rapidly, financially support some financial institutions and intervening several failing privatesector banks.

\subsection{Bank Credit}

The loss of deposits during the crisis led banks to cut down on credit. In 2002 the stock of dollardenominated credit (which accounted for about two-thirds of total credit) dropped by 16.1 percent. The stock of dollar credit continued falling until October 2006 and as of October 2011 had still not returned to its pre-crisis peak (see Figure 2). Meanwhile, the stock of pesodenominated credit dropped by 12.8 percent in 2002 and continued falling until February 2005, only returning to its pre-crisis peak in December 2007. Despite the recovery, credit growth tended to fall behind growth in activity. Credit to GDP fell every year between 2002 and 2007, 
and by the end of 2010 the ratio of credit to GDP stood at barely one third of its pre-crisis level (see Figure 3).

Figure 2. Average Credit Stock (in millions of US\$)

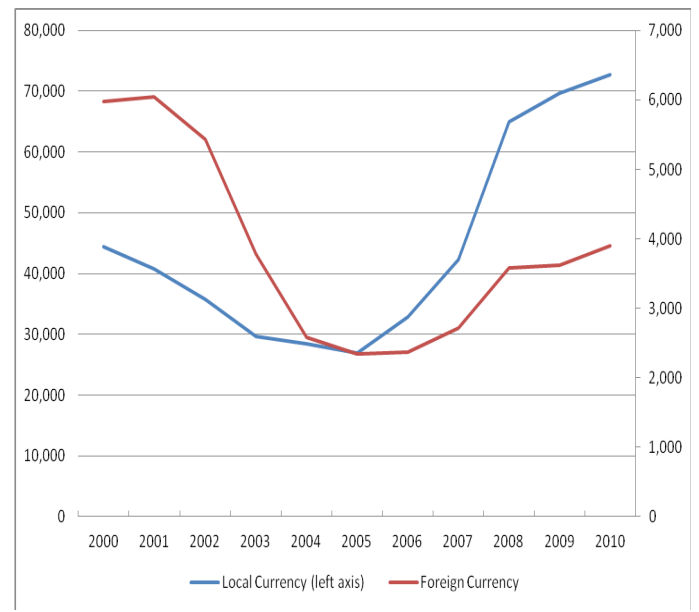

\section{Figure 3. Evolution of Credit/GDP Ratio}

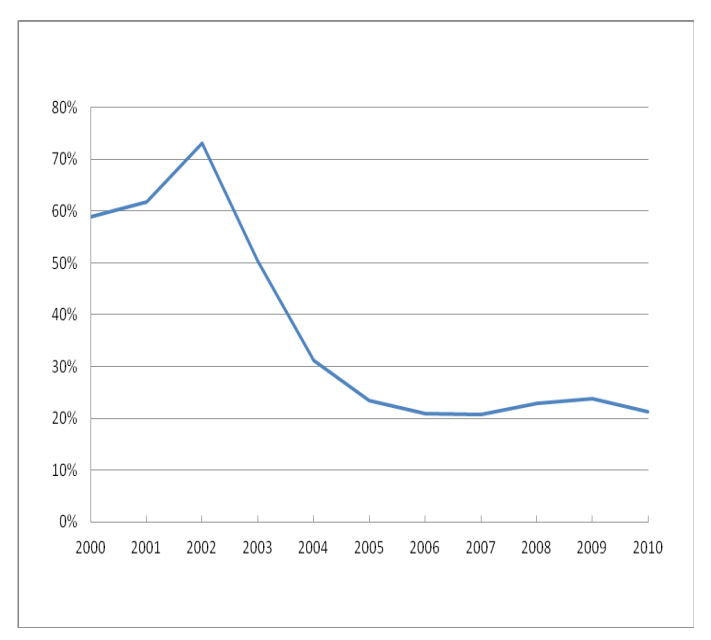

\subsection{Informality}

As could be expected, employment informality followed a countercyclical pattern during this period. Figure 4 shows the evolution of informality between 2000 and 2010. According to all three measures, informality rose during the economic crisis and decreased during most years of the subsequent recovery. 


\section{Figure 4. Evolution of Employment Informality}

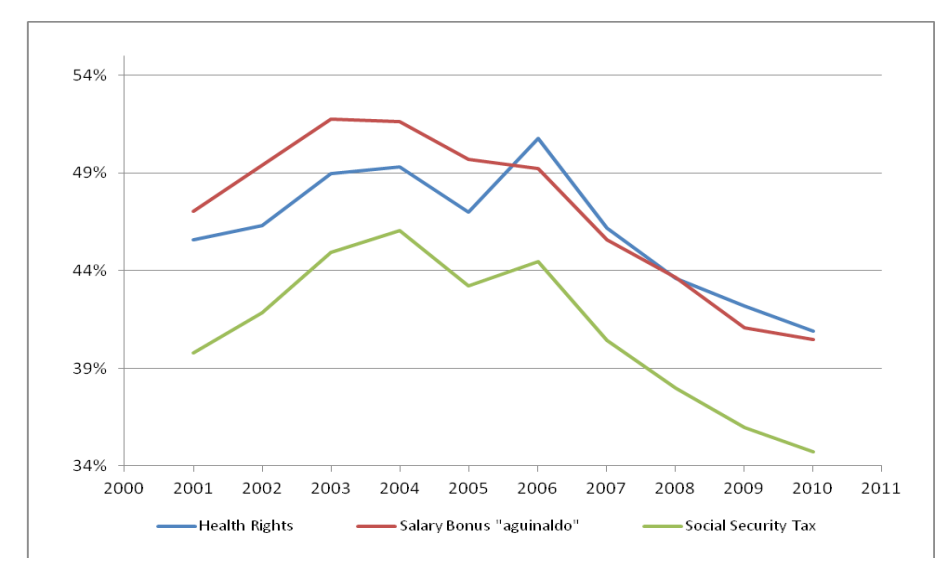

Even though informality in most sectors followed a similar trend during this period, there were important differences in the changes in sector-level informality. Given the goal of this paper, it is important to highlight differences in changes in informality according to the sector's dependence on external financing. Figure 5 plots the median of percentage changes in sectorlevel informality for sectors with high and low external financial dependence. The graph shows that between 2001 and 2005, when credit contracted sharply, informality rose in both types of sectors. But it increased relatively more in those sectors that are more dependent on external financing. Meanwhile, between 2005 and 2010, when credit grew, informality decreased in both types of sectors, but relatively more in sectors with high external financial dependence. 
Figure 5. Median Percentage Changes in Informality
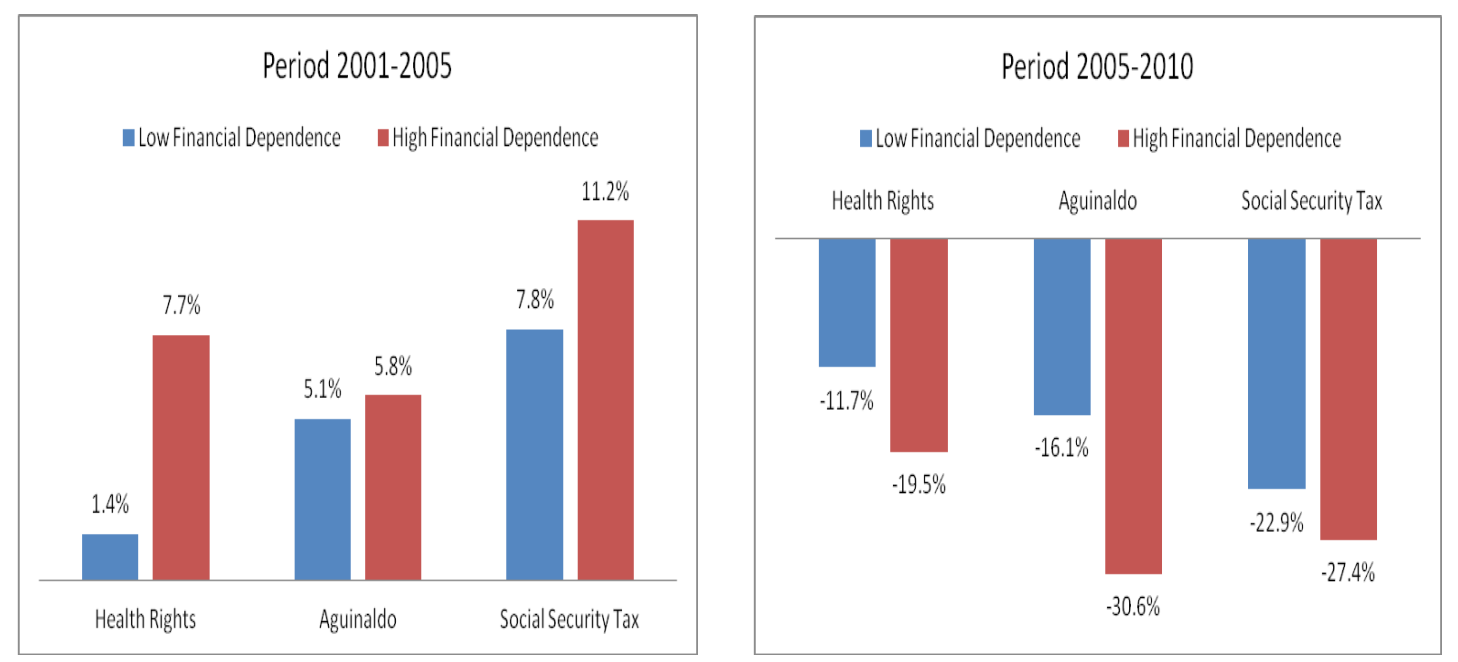

Note: Sectors are grouped into high and low financial dependence depending on whether their index of external financial dependence is above or below the average index for the sample of sectors considered.

\section{Methodology and Results}

\subsection{Econometric Model}

Following, we take advantage of sectoral differences in financial dependence to identify the effect of banking credit on formalization. The basic model to be estimated is:

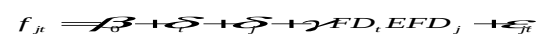

where the dependent variable $f_{j t}$ is the share of formal workers in sector $j$ at time $t$. The deltas are year and sector dummies. $F D_{t}$ is a measure of financial deepening and $E F D_{j}$ is a measure of external financial dependence at time $t$. The regressions were estimated by Generalized Least Squares (GLS) assuming a heteroskedastic but uncorrelated error structure.

The coefficient of interest is . For the estimation strategy to identify one needs both FD and EFD to be exogenous. The baseline measure of FD is the ratio of credit to the private sector to GDP. Given that most sectors considered are relatively small compared to the Uruguayan economy, and that they also account for only a small share of total credit to the private sector, our measure of FD can be considered exogenous. The baseline measure of external financing $(E F D)$ is computed on U.S. firms. Therefore, it should be exogenous for Uruguayan firms. 


\subsection{Baseline Results}

In Table 2 we report the first set of estimations. The coefficient reported is in equation 1 . The coefficient is significant at traditional statistical significance levels, implying that credit increases formality relatively more in sectors with higher financial dependence. The point estimates of the coefficient imply that a 10 percent increase in the ratio of credit to GDP increases formalization in the most financially dependent sector in the sample (Air transport) relative to the least financially dependent sector (Publishing, printing and reproduction of recorded media) by between 7.8 and 12.1 percentage points, depending on the definition of informality used. We also estimate via GLS, allowing the error term to follow a first-order autocorrelation process specific to each sector. The coefficients obtained are once again significant, and the point estimates are smaller than the ones obtained using panel GLS estimation with heteroskedastic but uncorrelated error. The point estimates imply that a 10 percent increase in the ratio of credit to GDP increases formalization in the most financially dependent sector in the sample relative to the least financially dependent sector by between 5.9 and 10.9 percentage points. ${ }^{11}$

\footnotetext{
Table 2. Formal Employment and Financial Dependence

Dependent variable: share of formal to total employment according to various definitions

Independent variable: Credit to the private sector (as percentage of GDP) interacted with RZ

Estimation method: various alternatives

Time and sector dummies included in all regressions

\begin{tabular}{|c|lcccc|}
\hline & & coeff. $^{* *}$ & s.e. & Obs. & Sectors \\
\hline Panel GLS estimation & Health rights ${ }^{11}$ & $28.972^{* * *}$ & 8.993 & 332 & 36 \\
with heteroskedastic but & Salary bonus "aguinaldo"/2 $^{* *}$ & $28.017^{* * *}$ & 8.518 & 305 & 36 \\
uncorrelated error & Social security taxes $^{\prime 2}$ & $18.553^{* *}$ & 7.926 & 305 & 36 \\
\hline Panel GLS estimation & Health rights $^{11}$ & $21.458^{* *}$ & 10.301 & 331 & 35 \\
with panel-specific AR1 & Salary bonus "aguinaldo"/2 $^{* 2}$ & $26.048^{* * *}$ & 9.967 & 304 & 35 \\
autocorrelation & Social security taxes $^{\prime 2}$ & $14.029^{*}$ & 7.891 & 304 & 35 \\
\hline
\end{tabular}

Note: Standard errors in parentheses * significant at 10\%; ** significant at 5\%; *** significant at $1 \%$.

${ }^{11}$ Period: 2000-2010. ${ }^{/ 2}$ Period: 2001-2010.

\subsection{Robustness Checks}

${ }^{11}$ These estimates are larger than the ones obtained by Catão, Pagés and Rosales (2009) using data from Brazil. The coefficient they report would imply a $4.5 \%$ increase in formalization for the most financially dependent sector relative to the least financially dependent sector, if a $10 \%$ increase in the ratio of credit/GDP were to take place. It is worth mentioning that Catão, Pagés and Rosales (2009) use a different EFD measure than we use in this paper. Their results are currently being revised.
} 
In Table 3 we explore the robustness of the previous result by considering an alternative measure of financial deepening (FD). We consider the sector's credit/GDP ratio as an alternative measure, doing so because of concerns that the overall credit/GDP ratio might fail to reflect differences in the evolution in credit availability for firms in different sectors. As long as firm production is relatively small compared to the total output in the sector, and as long as it represents a small share of total credit to the sector, this measure should not suffer from endogeneity problems. Given that sectoral credit is only available for the 2005-2010 period, the re-estimation of equation (1) is done over this shorter period of time. The coefficients of interest are once again positive and significant, suggesting that bank credit has a positive effect on employment formality.

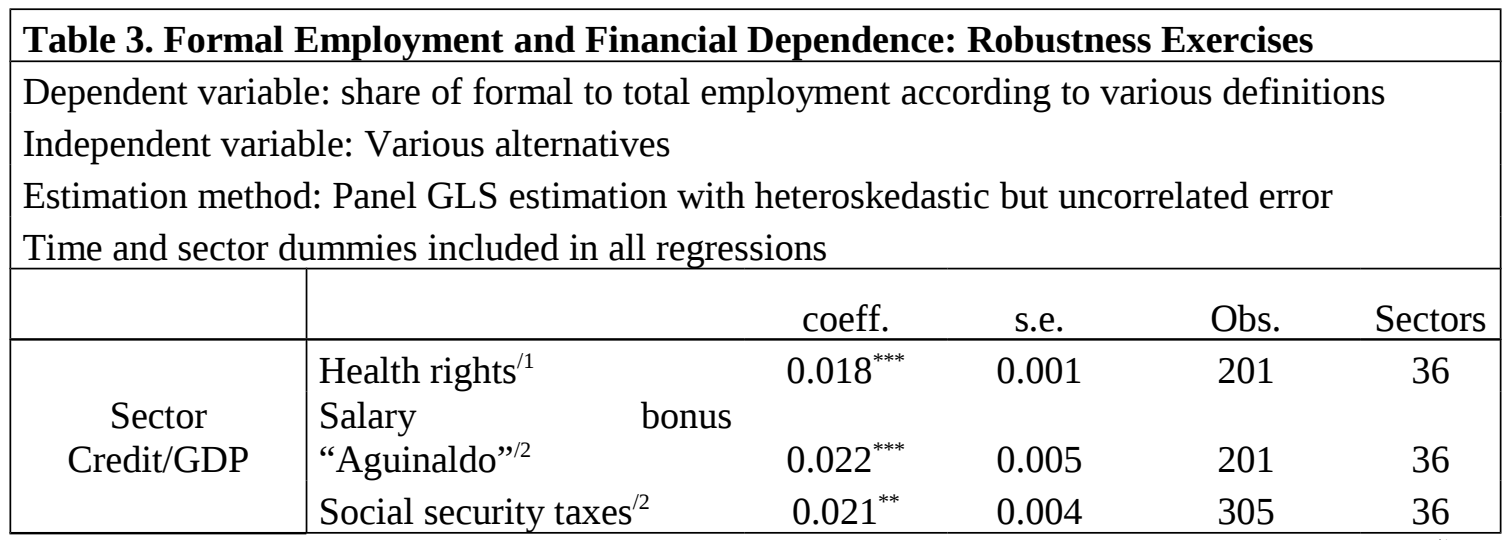

Note: Standard errors in parentheses * significant at $10 \%$; ${ }^{* *}$ significant at $5 \%$; ${ }^{* * *}$ significant at $1 \%{ }^{11}$ Period: 2000-2010. ${ }^{2}$ Period: 2001-2010

Finally, we consider an alternative measure for external financial dependence (EFD). The use of EFD measures obtained from firms in developed countries as proxies for sectoral external financial dependence in developing countries is often criticized because of the underlying assumption that developed and developing economies have similar production and financing need structures. This criticism is less relevant if ,instead of using sector-specific measures, one uses a coarser index of financial dependence. Following Catão, Pagés and Rosales, we re-estimate equation (1) using as the EFD index a dummy variable, defined as 1 if the sector has an aboveaverage FD index and zero otherwise. We once again find a positive and significant when the health rights and aguinaldo definitions are used, but they are not significant for the social security 
tax definition (see Table 4). All point estimates are higher than those obtained using the baseline EFD measure.

\begin{tabular}{|c|c|c|c|c|c|}
\hline \multicolumn{6}{|c|}{$\begin{array}{l}\text { Table 4. Formal Employment and Financial Dependence: Robustness Exercises } \\
\text { Dependent variable: share of formal to total employment according to various definitions } \\
\text { Independent variable: Various alternatives } \\
\text { Estimation method Panel GLS estimation with heteroskedastic but uncorrelated error } \\
\text { Time and sector dummies included in all regressions }\end{array}$} \\
\hline & & coeff. & s.e. & Obs. & Sectors \\
\hline \multirow{3}{*}{ Dummy EFD } & Health rights $^{1}$ & $58.896^{* * *}$ & 17.928 & 337 & 37 \\
\hline & Salary bonus "aguinaldo"/2 & $51.471^{* * *}$ & 17.481 & 310 & 37 \\
\hline & Social security taxes ${ }^{2}$ & 23.980 & 16.720 & 310 & 37 \\
\hline
\end{tabular}

Note: Standard errors in parentheses * significant at $10 \%$; ${ }^{* *}$ significant at $5 \%$; ${ }^{* * *}$ significant at $1 \%{ }^{11}$ Period: 2000-2010. ${ }^{2}$ Period: 2001-2010.

\subsection{Group-Specific Effects}

An interesting question to look at is whether there are differential effects of bank credit on the formality of different types of workers. To answer this question, we redefine the dependent variable $f_{j t}$ in equation (1) as the share of formal workers of a given type $c$ in sector $j$ at time $t$ and re-estimate that equation for different types of workers.

We first look at differences by gender group. Results in Table 5 show that except for the Aguinaldo definition of male formality, the coefficient of interest is positive and significant for both males and female. Nevertheless, the effect on females seems to be higher than those for males. The point estimates of the effect on women are between 4.3 and 4.8 times higher than those for males. 


\section{Table 5. Formal Employment and Financial Dependence: Gender break}

Dependent variable: share of formal to total employment.

Independent variable: Credit to the private sector (as percentage of GDP) interacted with RZ

Estimation method: Panel GLS estimation with heteroskedastic but uncorrelated error

Time and sector dummies included in all regressions

\begin{tabular}{|c|lcccc|}
\hline & & & & \\
& & coeff. & s.e. & Obs. & Sectors \\
\hline \multirow{2}{*}{ Health rights $^{\prime 1}$} & Males & $23.883^{* *}$ & 11.534 & 305 & 35 \\
& Females & $115.244^{* * *}$ & 8.964 & 200 & 23 \\
\hline Salary bonus & Males & 15.448 & 10.946 & 280 & 35 \\
"aguinaldo"'/2 $^{*}$ Social security taxes & Females & $67.127^{* * *}$ & 16.571 & 186 & 23 \\
& Males & $20.893^{* *}$ & 10.490 & 280 & 35 \\
& Females & $99.090^{* * * *}$ & 14.199 & 186 & 23 \\
\hline
\end{tabular}

Note: Standard errors in parentheses * significant at $10 \%$; ** significant at $5 \%$; ** significant at $1 \%{ }^{11}$ Period: 2000-2010. ${ }^{2}$ Period: 2001-2010.

Important differences also emerge when one looks at different age groups (see Table 6). We consider two age groups: workers up to 25 years of age and workers 26 years of age or older. Except for the social security definition of formality for workers 26 years of age or older, the coefficient of interest is positive and significant for younger and older workers. Nevertheless, the point estimates of the effect on workers aged 25 or younger are between 2.8 and 14.7 times higher than those for males.

\section{Table 6. Formal Employment and Financial Dependence: Age break}

Dependent variable: share of formal to total employment.

Independent variable: Credit to the private sector (as percentage of GDP) interacted with RZ

Estimation method: Panel GLS estimation with heteroskedastic but uncorrelated error Time and sector dummies included in all regressions

\begin{tabular}{|c|c|c|c|c|c|}
\hline & & coeff. & s.e. & Obs. & Sectors \\
\hline \multirow{2}{*}{ Health rights ${ }^{1}$} & up to 25 years old & $73.198^{* * *}$ & 19.636 & 197 & 25 \\
\hline & more than 25 years old & $26.192^{* * *}$ & 8.958 & 321 & 35 \\
\hline \multirow{2}{*}{$\begin{array}{l}\text { Salary bonus } \\
\text { "aguinaldo"/2 }\end{array}$} & up to 25 years old & $129.862^{* * *}$ & 21.373 & 181 & 25 \\
\hline & more than 25 years old & $24.074^{* * *}$ & 9.127 & 294 & 35 \\
\hline \multirow{2}{*}{$\begin{array}{c}\text { Social security } \\
\text { taxes }^{\prime 2}\end{array}$} & up to 25 years old & $116.379^{* * *}$ & 20.741 & 181 & 25 \\
\hline & more than 25 years old & 7.909 & 8.475 & 294 & 35 \\
\hline
\end{tabular}

Note: Standard errors in parentheses * significant at $10 \%$; ${ }^{* *}$ significant at $5 \%$; ${ }^{* * *}$ significant at $1 \%{ }^{11}$ Period: 2000-2010. ${ }^{2}$ Period: 2001-2010. 
Given that the number of sectors included in the regressions for younger workers and for females is lower than the sectors included in the regressions of older workers and male workers, one might be concerned that the differences in the reported effects are due to sector composition effects. To rule out this possibility we re-estimate Tables 5 and 6 restricting to the common set of sectors. The results (not reported) with age breaks do not change qualitatively but the positive effect on men is no longer significant. Therefore, the differential impact of bank credit on women and men is even higher that what is suggested by Table 5.

Finally, we look at whether differences emerge when one consider workers employed by firms of different sizes. We consider three size groups: self-employed, those working in firms with between 2 and 10 employees, and those working in firms with more than 10 employees. For all three measures of formality, we find statistically significant effects of credit on formalization of workers employed by firms with more than 10 employees. For other firm sizes, the effect is not significant for some measures of informality (see Table 7). The effect is higher for larger firms according to all informality measures.

\section{Table 7. Formal Employment and Financial Dependence: Firm size break}

Dependent variable: share of formal to total employment.

Independent variable: Credit to the private sector (as percentage of GDP) interacted with RZ

Estimation method: Panel GLS estimation with heteroskedastic but uncorrelated error structure Time and sector dummies included in all regressions

\begin{tabular}{|c|lcccc|}
\hline & & coeff. & s.e. & Obs. & Sectors \\
\hline \multirow{2}{*}{$\begin{array}{c}\text { Health } \\
\text { rights }\end{array}$} & Self-employed & $38.622^{* * *}$ & 10.25 & 199 & 26 \\
& Firms with 2 to 10 employees & $35.907^{* * *}$ & 11.564 & 218 & 26 \\
& Firms with more than 10 employees & $41.774^{* * *}$ & 8.140 & 271 & 33 \\
\hline \multirow{2}{*}{$\begin{array}{c}\text { Salary bonus } \\
\text { "aguinaldo"/2 }\end{array}$} & Self employed & 4.783 & 4.777 & 183 & 26 \\
& Firms with 2 to 10 employees & 16.896 & 11.649 & 202 & 26 \\
& Firms with more than 10 employees & $32.651^{* * *}$ & 8.159 & 250 & 33 \\
\hline Social & Self employed & $26.269^{* *}$ & 11.702 & 183 & 26 \\
security $_{\text {taxes }}{ }^{2}$ & Firms with 2 to 10 employees & 19.064 & 12.090 & 202 & 26 \\
& Firms with more than 10 employees & $38.483^{* * *}$ & 8.133 & 250 & 33 \\
\hline
\end{tabular}

Note: Standard errors in parentheses * significant at $10 \%$; ** significant at $5 \%$; *** significant at $1 \%{ }^{11}$ Period: 2000-2010. ${ }^{2}$ Period: 2001-2010

\subsection{Time-Varying Effects}


As mentioned above, the economic crisis in Uruguay led to sharp contraction of credit and to an important restructuring of the banking sector. Given these events, it is interesting to examine whether the size of the effects of bank credit on informality has changed over time. To do this, we re-estimate equation (1) for different six-year periods (see Table 8). Even though point estimates suggest that the effect might have increased over time, the effects for the later years are more imprecisely estimated, and therefore differences in point estimates are not statistically significant. It thus appears that that the size of the effect of bank credit on informality has remained constant over time. Similar results are obtained if either shorter or longer time periods are defined for the estimation of equation (1).

\begin{tabular}{|c|c|c|c|c|c|}
\hline \multicolumn{6}{|c|}{ Table 8. Formal Employment and Financial Dependence: Business cycle } \\
\hline \multicolumn{6}{|c|}{$\begin{array}{l}\text { Dependent variable: share of formal to total employment according to various definitions } \\
\text { Independent variable: Credit to the private sector (as percentage of GDP) interacted with RZ } \\
\text { Estimation method: Panel GLS estimation with heteroskedastic but uncorrelated error } \\
\text { Time and sector dummies included in all regressions }\end{array}$} \\
\hline Estimation method & Periods & coeff. & s.e. & Obs & Sectors \\
\hline \multirow{6}{*}{ Health rights } & $2000-2005$ & $30.52^{* *}$ & 11.92 & 157 & 27 \\
\hline & 2001-2006 & $32.76^{* * *}$ & 9.79 & 165 & 35 \\
\hline & 2002-2007 & $28.55^{* * *}$ & 11.06 & 173 & 35 \\
\hline & 2003-2008 & $64.05^{* * *}$ & 19.11 & 182 & 35 \\
\hline & 2004-2009 & 67.96 & 53.49 & 191 & 35 \\
\hline & $2005-2010$ & 160.25 & 133.79 & 201 & 36 \\
\hline \multirow{5}{*}{$\begin{array}{l}\text { Salary bonus } \\
\text { "aguinaldo" }\end{array}$} & 2001-2006 & $33.19^{* * *}$ & 7.83 & 165 & 35 \\
\hline & $2002-2007$ & $25.59^{* * *}$ & 8.47 & 173 & 35 \\
\hline & 2003-2008 & $61.65^{* * *}$ & 14.52 & 182 & 35 \\
\hline & 2004-2009 & $114.16^{* *}$ & 46.47 & 191 & 35 \\
\hline & $2005-2010$ & 73.99 & 140.92 & 201 & 36 \\
\hline \multirow{5}{*}{ Social security taxes } & 2001-2006 & 10.36 & 8.52 & 165 & 35 \\
\hline & $2002-2007$ & 9.36 & 9.16 & 173 & 35 \\
\hline & 2003-2008 & $52.11^{* * *}$ & 18.94 & 182 & 35 \\
\hline & 2004-2009 & 32.05 & 50.99 & 191 & 35 \\
\hline & 2005-2010 & 76.76 & 133.46 & 201 & 36 \\
\hline
\end{tabular}

Note: Standard errors in parentheses * significant at 10\%; ** significant at 5\%; *** significant at $1 \%$. 


\section{Conclusions}

In this paper we followed the Catão, Pagés and Rosales methodology to study the impact of bank credit on employment formality. In our Uruguayan sample, we find that easier access to bank credit decreases informality, especially in more financially dependent sectors. This effect is found to be larger for women, younger workers and workers employed by larger firms. No evidence is found that the effect of bank credit on formality has changed over time.

Even though our analysis is able to unveil a positive effect of bank credit on employment formality, our work is silent on what explains the magnitude of the effect as well as the differential effects across different types of workers. Understanding how the economy's underlying key parameters and institutions affect the impact of bank credit on informality is of outmost importance. These topics, beyond the scope of this paper, call for further research. 


\section{References}

Amarante, V. and R. Arim. 2005. "Empleo Informal en Uruguay.” In: Algunos Factores a Tener en Cuenta para la Participación de las Micro y Pequeñas Empresas en el Desarrollo Económico Local y la Generación de Empleo Decente en Uruguay. Documento de trabajo. Bilbao, Spain: Programa REDEL.

Antman, F. and D.J. McKenzie. 2005. "Earnings Mobility and Measurement Error: A PseudoPanel Approach.” Stanford, United States: Stanford University. Mimeographed document.

Beck, T., R. Levine and N. Loayza. 2000. "Finance and the Sourcesof Growth." Journal of Financial Economics (58): 261-300.

Benedetti, E. 2007. "Empleo Informal en el Uruguay.” INE Informe Temático Encuesta de Hogares Ampliada 2006. Montevideo, Uruguay: Instituto Nacional de Estadísticas (INE).

Brasca, M. et al. 2009. "La Informalidad en Uruguay: Diagnóstico y Propuestas.” Montevideo, Uruguay: Universidad Católica del Uruguay. Available at: http://www.cncs.com.uy/docs/La\%20informalidad\%20en\%20el\%20Uruguay.pdf

Buscio, V., N. Gandelman and H. Kamil. 2011. "Exposición Cambiaria y Uso de Instrumentos Derivados en Economías Dolarizadas: Evidencia Microeconómica para Uruguay.” Montevideo, Uruguay: Universidad ORT. Unpublished manuscript.

Cassoni, A. 2001. "Unemployment and Precariousness of Employment in Uruguay: Who Are the Losers?” Documento 16/01. Montevideo, Uruguay: Universidad de la República, Facultad de Ciencias Económicas y Administración, Departamento de Economía.

Catão, L., C. Pagés and M.F. Rosales. 2009. "Financial Dependence, Formal Credit and Informal Jobs: New Evidence from Brazilian Household Data.” IDB-WP-118. Washington, DC, United States: Inter-American Development Bank.

Catão, L., C. Pagés and M.F. Rosales. 2011. "Financial Dependence, Formal Credit and Informal Jobs: New Evidence from Brazilian Household Data.” Washington, DC, United States: Inter-American Development Bank. Manuscript (revision of IDB-WP-118).

Central Intelligence Agency. 2011. The World Factbook. Washington, DC, United States: Central Intelligence Agency. Available at: https://www.cia.gov/library/publications/the-worldfactbook/ 
Deaton, A. 1985. "Panel Data from Times Series of Cross-Sections.” Journal of Econometrics (30): 109-126.

De Brun, J., N. Gandelman and E. Barbieri. 2003. "Investment Equations and Financial Restrictions at Firm Level: The Case of Uruguay.” In: A. Galindo and F. Schiantarelli, editors. Credit Constraints and Investment in Latin America. Washington, DC, United States: Inter-American Development Bank.

D’Erasmo, P.N. and H.J. Moscoso Boedo. 2009. "Financial Structure, Informality, and Development.” College Park, Maryland, United States: University of Maryland. Mimeographed document.

Diez de Medina, R. and P. Gerstenfeld. 1986. "Sector Informal Urbano: Marco Teórico, Cuantificación y Propuesta de Medición para el Caso Uruguayo.” Paper presented at Primeras Jornadas Anuales de Economía, Banco Central del Uruguay, Montevideo, Uruguay.

Farrell, D. 2001. "The Hidden Dangers of the Informal Economy.” McKinsey Quarterly (3): 2737.

----. 2006. The Productivity Imperative: Wealth and Poverty in the Global Economy. Cambridge, United States: McKinsey Global Institute/Harvard Business School Press.

Filgueira, F. and D. Gelber. 2003. "La Informalidad en Uruguay: ¿Un Mecanismo de Adaptación del Trabajo o del Capital.” Serie Documentos de Trabajo del IPES/ Colección Monitor Social del Uruguay 5. Montevideo, Uruguay: Universidad Católica del Uruguay.

Gasparini, L. and L. Tornarolli. 2007. "Labor Informality in Latin America and the Caribbean: Patterns and Trends from Household Survey Microdata.” Documento de Trabajo 46. La Plata, Argentina: Centro de Estudios Distributivos, Laborales y Sociales.

Graziani, C. 1988. "La Demanda de Circulante y la Economía Informal: Algunas Estimaciones para el Caso de Uruguay.” Paper presented at Terceras Jornadas Anuales de Economía, Banco Central del Uruguay, Montevideo, Uruguay.

Hsieh, C-T., and P. Klenow. 2009. "Misallocation and Manufacturing TFP in China and India." Quarterly Journal of Economics 124(4): 1403-1448. 
Instituto Cuesta Duarte. 2002. "Informalidad y Seguridad Social en Uruguay.” Montevideo, Uruguay: Friederich Ebert Stiftung, Equipo de Representación de los Trabajadores en el Banco de Previsión Social.

Inter-American Development Bank (IDB). 2010. The Age of Productivity: Transforming Economies from the Bottom Up. Development in the Americas Report. Washington, DC, United States: IDB.

International Labour Organization (ILO) Department of Statistics. 2011. Statistical Update on Employment in the Informal Economy. Geneva, Switzerland: ILO.

La Porta, R., and A. Shleifer. 2008. The Unofficial Economy and Economic Development. NBER Working Paper 14520. Cambridge, United States: National Bureau of Economic Research.

Levine, R. 1997. "Financial Development and Economic Growth: Views and Agenda.” Journal of Economic Literature 35(2): 688-726.

Levy, S. 2008. Good Intentions, Bad Outcomes: Social Policy, Informality, and Economic Growth in Mexico. Washington, DC, United States: Brookings Institution Press.

Longhi, A. 1999. "Delimitación y Medida del Sector Informal: Antecedentes y Fundamentos de Opción Metodológica.” Documento de Trabajo 40. Montevideo, Uruguay: Universidad de la República, Facultad de Ciencias Sociales, Departamento de Sociología.

Moffitt, R. 1993. "Identification and Estimation of Dynamic Models with a Time Series of Repeated Cross-Sections.” Journal of Econometrics 59: 99-123.

Munyo, I. 2005. "The Determinants of Capital Structure: Evidence from an Economy without [a] Stock Market.” Montevideo, Uruguay: Centro de Estudios de la Realidad Económica y Social. Manuscript.

Perry, G. et al. 2008. Informality: Exit and Exclusion. Washington, DC, United States: World Bank.

Rajan, R., and L. Zingales. 1998. "Financial Dependence and Growth.” American Economic Review 88: 559-586.

Verbeek, M., and F. Vella. 2002. "Estimating Dynamic Models from Repeated Cross-Sections." Leuven, Belgium: Katholieke Universiteit Leuven Center for Economic Studies. Mimeographed document. 
Documento de investigación - ISSN 1688-6275 - No. 75 - 2012 - Gandelman, N., Rasteletti, A.

World Bank. 2011. Doing Business. http://www.doingbusiness.org

World Economic Forum (WEF). 2010. The Global Competitiveness Report 2010-2011. Davos, Switzerland: WEF. 


\section{Appendix}

\begin{tabular}{|c|c|c|c|c|c|c|c|c|c|}
\hline & \multicolumn{3}{|c|}{ Health Rights } & \multicolumn{3}{|c|}{ Salary Bonus "aguinaldo" } & \multicolumn{3}{|c|}{ Social Security Tax } \\
\hline & 2001 & 2005 & 2010 & 2001 & 2005 & 2010 & 2001 & 2005 & 2010 \\
\hline Total & $45.58 \%$ & $47.02 \%$ & $40.95 \%$ & $47.05 \%$ & $49.73 \%$ & $40.61 \%$ & $39.82 \%$ & $43.29 \%$ & $34.81 \%$ \\
\hline \multicolumn{10}{|l|}{ Firm Size } \\
\hline Self & $85.35 \%$ & $83.95 \%$ & $79.32 \%$ & $97.70 \%$ & $98.43 \%$ & $99.05 \%$ & $76.72 \%$ & $78.22 \%$ & $76.45 \%$ \\
\hline 2 to 9 & $50.64 \%$ & $54.69 \%$ & $50.24 \%$ & $48.26 \%$ & $52.51 \%$ & $45.53 \%$ & $44.42 \%$ & $50.37 \%$ & $44.67 \%$ \\
\hline 10 or more & $12.82 \%$ & $12.78 \%$ & $13.88 \%$ & $9.04 \%$ & $10.14 \%$ & $4.93 \%$ & $9.49 \%$ & $11.06 \%$ & $5.56 \%$ \\
\hline \multicolumn{10}{|l|}{ Gender } \\
\hline Male & $48.30 \%$ & $49.42 \%$ & $41.51 \%$ & $49.87 \%$ & $52.40 \%$ & $41.54 \%$ & $43.02 \%$ & $45.95 \%$ & $36.29 \%$ \\
\hline Female & $41.20 \%$ & $43.30 \%$ & $40.16 \%$ & $42.50 \%$ & $45.59 \%$ & $39.28 \%$ & $34.66 \%$ & $39.18 \%$ & $32.71 \%$ \\
\hline \multicolumn{10}{|c|}{ 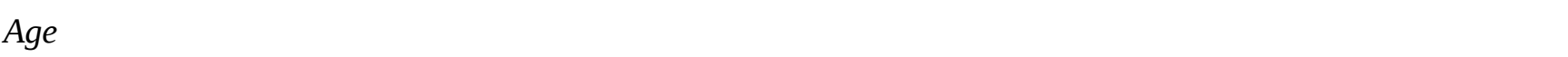 } \\
\hline Up to 25 & $49.27 \%$ & $51.80 \%$ & $42.25 \%$ & $44.98 \%$ & $48.01 \%$ & $35.08 \%$ & $46.80 \%$ & $50.11 \%$ & $39.00 \%$ \\
\hline 26 years of & $44.60 \%$ & $45.90 \%$ & $40.64 \%$ & $47.61 \%$ & $50.13 \%$ & $41.94 \%$ & $37.96 \%$ & $41.70 \%$ & $33.81 \%$ \\
\hline
\end{tabular}

Note: For all years and definitions in the table, differences between males and females, self-employed and 2 to 9 employees, 2 to 9 and 10 or more employees are statistically significant at a $1 \%$ confidence level. The difference between workers up to 25 years of age and 26 years or older is significant at a 10\% confidence level in 2005 when the Aguinaldo definition is used. In all other cases, the difference for the two age groups is significant at a $1 \%$ level. 
Documento de Investigación - ISSN 1688-6208 - No. 75 - 2012 - Gandelman, N., Rasteletti, A.

\begin{tabular}{|c|c|c|c|c|c|c|c|c|c|c|}
\hline \multirow{2}{*}{ ISIC } & \multirow{2}{*}{ Sector } & \multicolumn{3}{|c|}{ Health Rights } & \multicolumn{3}{|c|}{ Salary Bonus "aguinaldo" } & \multicolumn{3}{|c|}{ Social Security Tax } \\
\hline & & 2001 & 2005 & 2010 & 2001 & 2005 & 2010 & 2001 & 2005 & 2010 \\
\hline 13 & Mining of metal ores & $0.00 \%$ & N/A & $5.56 \%$ & $100.00 \%$ & N/A & $0.00 \%$ & $0.00 \%$ & N/A & $0.00 \%$ \\
\hline 14 & Other mining and quarrying & $35.00 \%$ & $27.27 \%$ & $28.40 \%$ & $40.00 \%$ & $27.27 \%$ & $22.22 \%$ & $30.00 \%$ & $27.27 \%$ & $22.22 \%$ \\
\hline 15 & Manufacture of food products and beverages & $30.49 \%$ & $30.40 \%$ & $24.95 \%$ & $26.81 \%$ & $25.37 \%$ & $17.13 \%$ & $27.21 \%$ & $28.34 \%$ & $19.38 \%$ \\
\hline 17 & Manufacture of textiles & $30.49 \%$ & $38.35 \%$ & $44.97 \%$ & $31.71 \%$ & $38.35 \%$ & $48.66 \%$ & $30.49 \%$ & $39.10 \%$ & $48.66 \%$ \\
\hline 18 & Manufacture of wearing apparel & $72.09 \%$ & $73.13 \%$ & $64.56 \%$ & $74.27 \%$ & $75.47 \%$ & $69.51 \%$ & $69.17 \%$ & $73.36 \%$ & $68.24 \%$ \\
\hline 19 & Tanning and dressing of leather & $33.33 \%$ & $25.23 \%$ & $28.20 \%$ & $31.85 \%$ & $27.03 \%$ & $25.56 \%$ & $29.63 \%$ & $24.32 \%$ & $22.56 \%$ \\
\hline 20 & Manufacture of wood and of products of wood and cork & $65.05 \%$ & $67.50 \%$ & $51.93 \%$ & $64.08 \%$ & $70.00 \%$ & $45.61 \%$ & $61.17 \%$ & $67.50 \%$ & $49.12 \%$ \\
\hline 21 & Manufacture of paper and paper products & $25.00 \%$ & $28.57 \%$ & $13.14 \%$ & $25.00 \%$ & $22.45 \%$ & $10.22 \%$ & $25.00 \%$ & $28.57 \%$ & $8.76 \%$ \\
\hline 22 & Publishing, printing and reproduction of recorded media & $27.08 \%$ & $34.42 \%$ & $24.71 \%$ & $26.39 \%$ & $33.77 \%$ & $21.76 \%$ & $23.61 \%$ & $31.82 \%$ & $17.94 \%$ \\
\hline 23 & Manufacture of coke, refined petroleum prod. and nuclear fuel & $28.57 \%$ & $0.00 \%$ & $25.00 \%$ & $28.57 \%$ & $0.00 \%$ & $0.00 \%$ & $28.57 \%$ & $0.00 \%$ & $0.00 \%$ \\
\hline 24 & Manufacture of chemicals and chemical products & $12.15 \%$ & $13.81 \%$ & $14.49 \%$ & $10.50 \%$ & $11.60 \%$ & $5.94 \%$ & $9.39 \%$ & $12.15 \%$ & $5.94 \%$ \\
\hline 25 & Manufacture of rubber and plastics products & $11.58 \%$ & $13.16 \%$ & $14.96 \%$ & $10.53 \%$ & $11.84 \%$ & $5.56 \%$ & $10.53 \%$ & $13.16 \%$ & $7.26 \%$ \\
\hline 26 & Manufacture of other non-metallic mineral products & $66.95 \%$ & $74.44 \%$ & $55.76 \%$ & $65.25 \%$ & $73.33 \%$ & $52.04 \%$ & $64.41 \%$ & $72.22 \%$ & $52.42 \%$ \\
\hline 27 & Manufacture of basic metals & $30.77 \%$ & $40.00 \%$ & $35.71 \%$ & $38.46 \%$ & $20.00 \%$ & $21.43 \%$ & $23.08 \%$ & $30.00 \%$ & $28.57 \%$ \\
\hline 28 & Manufacture of fabricated metal products & $45.97 \%$ & $45.41 \%$ & $41.15 \%$ & $47.58 \%$ & $47.96 \%$ & $40.63 \%$ & $40.73 \%$ & $43.37 \%$ & $37.67 \%$ \\
\hline 29 & Manufacture of machinery and equipment n.e.c. & $29.27 \%$ & $31.58 \%$ & $28.05 \%$ & $31.71 \%$ & $39.47 \%$ & $36.59 \%$ & $29.27 \%$ & $26.32 \%$ & $28.66 \%$ \\
\hline 31 & Manufacture of electrical machinery and apparatus n.e.c. & $33.33 \%$ & $31.25 \%$ & $24.32 \%$ & $27.78 \%$ & $31.25 \%$ & $10.81 \%$ & $33.33 \%$ & $25.00 \%$ & $9.46 \%$ \\
\hline 32 & Manufacture of radio, television and communication equip. & $40.00 \%$ & $30.00 \%$ & $9.09 \%$ & $40.00 \%$ & $20.00 \%$ & $18.18 \%$ & $40.00 \%$ & $10.00 \%$ & $18.18 \%$ \\
\hline 33 & Manufacture of medical, precision and optical instruments & $10.53 \%$ & $53.57 \%$ & $30.59 \%$ & $26.32 \%$ & $60.71 \%$ & $43.53 \%$ & $5.26 \%$ & $46.43 \%$ & $22.35 \%$ \\
\hline 34 & Manufacture of motor vehicles, trailers and semi-trailers & $0.00 \%$ & $0.00 \%$ & $3.03 \%$ & $14.29 \%$ & $7.69 \%$ & $0.00 \%$ & $0.00 \%$ & $0.00 \%$ & $0.00 \%$ \\
\hline
\end{tabular}




\section{Table A2 (continued). Summary statistics of alternative measures of informality}

\begin{tabular}{|c|c|c|c|c|c|c|c|c|c|c|}
\hline \multirow{2}{*}{ ISIC } & \multirow{2}{*}{ Sector } & \multicolumn{3}{|c|}{ Health Rights } & \multicolumn{3}{|c|}{ Salary Bonus "aguinaldo" } & \multicolumn{3}{|c|}{ Social Security Tax } \\
\hline & & 2001 & 2005 & 2010 & 2001 & 2005 & 2010 & 2001 & 2005 & 2010 \\
\hline 35 & Manufacture of other transport equipment & $48.39 \%$ & $57.45 \%$ & $48.48 \%$ & $61.29 \%$ & $59.57 \%$ & $50.00 \%$ & $48.39 \%$ & $51.06 \%$ & $39.39 \%$ \\
\hline 36 & Manufacture of furniture; manufacturing n.e.c. & $70.43 \%$ & $74.63 \%$ & $64.93 \%$ & $73.48 \%$ & $77.21 \%$ & $71.64 \%$ & $66.52 \%$ & $73.90 \%$ & $66.27 \%$ \\
\hline 40 & Electricity, gas, steam and hot water supply & $43.75 \%$ & $20.00 \%$ & $8.64 \%$ & $18.75 \%$ & $20.00 \%$ & $3.70 \%$ & $25.00 \%$ & $20.00 \%$ & $4.94 \%$ \\
\hline 45 & Construction & $66.14 \%$ & $66.35 \%$ & $52.45 \%$ & $66.90 \%$ & $68.46 \%$ & $50.27 \%$ & $64.79 \%$ & $66.06 \%$ & $49.73 \%$ \\
\hline 50 & Sale, maintenance and repair of motor vehicles \& fuel & $51.40 \%$ & $53.53 \%$ & $48.61 \%$ & $53.88 \%$ & $55.13 \%$ & $49.82 \%$ & $47.20 \%$ & $51.44 \%$ & $45.91 \%$ \\
\hline 51 & Wholesale trade & $31.03 \%$ & $41.23 \%$ & $34.07 \%$ & $31.66 \%$ & $44.55 \%$ & $31.09 \%$ & $25.75 \%$ & $38.03 \%$ & $26.51 \%$ \\
\hline 52 & Retail and commission trade & $50.33 \%$ & $54.79 \%$ & $47.56 \%$ & $54.49 \%$ & $58.30 \%$ & $49.99 \%$ & $45.29 \%$ & $51.69 \%$ & $44.13 \%$ \\
\hline 55 & Hotels and restaurants & $41.24 \%$ & $43.56 \%$ & $43.07 \%$ & $35.92 \%$ & $41.45 \%$ & $38.14 \%$ & $35.92 \%$ & $40.92 \%$ & $37.20 \%$ \\
\hline 60 & Land transport; transport via pipelines & $24.37 \%$ & $28.52 \%$ & $23.88 \%$ & $32.05 \%$ & $37.52 \%$ & $26.05 \%$ & $20.70 \%$ & $25.98 \%$ & $17.75 \%$ \\
\hline 62 & Air transport & $3.85 \%$ & $11.11 \%$ & $20.37 \%$ & $3.85 \%$ & $11.11 \%$ & $5.56 \%$ & $3.85 \%$ & $11.11 \%$ & $5.56 \%$ \\
\hline 63 & Supporting transport activities; activities of travel agencies & $46.11 \%$ & $30.89 \%$ & $34.21 \%$ & $49.72 \%$ & $32.05 \%$ & $28.82 \%$ & $39.72 \%$ & $28.19 \%$ & $26.20 \%$ \\
\hline 64 & Post and telecommunications & $28.57 \%$ & $39.10 \%$ & $26.57 \%$ & $23.47 \%$ & $38.35 \%$ & $22.99 \%$ & $24.49 \%$ & $33.08 \%$ & $17.91 \%$ \\
\hline 70 & Real estate activities & $39.74 \%$ & $37.50 \%$ & $31.58 \%$ & $55.13 \%$ & $50.00 \%$ & $37.32 \%$ & $29.49 \%$ & $35.71 \%$ & $15.79 \%$ \\
\hline 72 & Computer and related activities & $32.11 \%$ & $43.81 \%$ & $36.43 \%$ & $47.71 \%$ & $55.67 \%$ & $43.21 \%$ & $26.61 \%$ & $35.05 \%$ & $23.30 \%$ \\
\hline 74 & Other business activities & $53.23 \%$ & $50.60 \%$ & $50.85 \%$ & $53.44 \%$ & $57.85 \%$ & $57.94 \%$ & $34.07 \%$ & $36.81 \%$ & $34.17 \%$ \\
\hline 80 & Education & $31.21 \%$ & $30.65 \%$ & $28.75 \%$ & $31.41 \%$ & $31.83 \%$ & $23.39 \%$ & $27.36 \%$ & $27.90 \%$ & $21.46 \%$ \\
\hline 85 & Health and social work & $24.35 \%$ & $23.67 \%$ & $25.75 \%$ & $23.86 \%$ & $25.71 \%$ & $21.59 \%$ & $15.11 \%$ & $17.47 \%$ & $13.45 \%$ \\
\hline 90 & Sewage and refuse disposal, sanitation and similar activities & $37.93 \%$ & $47.83 \%$ & $29.21 \%$ & $41.38 \%$ & $43.48 \%$ & $10.11 \%$ & $34.48 \%$ & $43.48 \%$ & $10.11 \%$ \\
\hline 92 & Recreational, cultural and sporting activities & $58.80 \%$ & $58.90 \%$ & $47.44 \%$ & $58.37 \%$ & $62.17 \%$ & $52.95 \%$ & $55.79 \%$ & $58.08 \%$ & $45.99 \%$ \\
\hline 93 & Other service activities & $69.03 \%$ & $71.31 \%$ & $63.64 \%$ & $77.17 \%$ & $78.83 \%$ & $72.96 \%$ & $64.83 \%$ & $69.92 \%$ & $61.45 \%$ \\
\hline
\end{tabular}

